\title{
ВПЛИВ МОЛЕКУЛИ ОПІОЇДНИХ ПРЕПАРАТІВ НА ПАТОМОРФОЛОГІЧНУ ДЕЗОРГАНІЗАЦІЮ ОРГАНІВ ТА СИСТЕМ
}

\author{
Івасівка Х. П., Пальтов Е. В., Кривко Ю. Я.
}

Львівський національний медичний університет імені Данила Галиџького, кафедра нормальної анатомії, м. Львів, Україна

DOI: https://doi.org/10.31435/rsglobal_ws/31082019/6635

\section{ARTICLE INFO}

Received: 11 June 2019

Accepted: 13 August 2019

Published: 31 August 2019

\section{KEYWORDS}

opioid influence, pathomorphology, heart, lungs, kidneys, adrenals, brain, lymphocytes.

\section{ABSTRACT}

The aim of our work was to study scientific information and statistics on pathomorphological manifestations in tissues, organs and systems of the body when exposed to a molecule of opioid drugs.

Citation: Ivasivka K., Paltov E., Kryvko Yu. (2019) The Influence of Opioid Molecules on the Pathomorphological Disorganization of Bodies and Systems. World Science. 8(48), Vol.2. doi: 10.31435/rsglobal_ws/31082019/6635

Copyright: (C) 2019 Ivasivka K., Paltov E., Kryvko Yu. This is an open-access article distributed under the terms of the Creative Commons Attribution License (CC BY). The use, distribution or reproduction in other forums is permitted, provided the original author(s) or licensor are credited and that the original publication in this journal is cited, in accordance with accepted academic practice. No use, distribution or reproduction is permitted which does not comply with these terms.

Результати статі відповідають плану наукових досліджень Львівського національного медичного університету імені Данила Галицького іє частиною науково - дослідної теми кафедри нормальної анатомії «Структурна організація, ангіоархітектоніки та антропометричні особливості органів у внутрішньо та позаутробному періодах розвитку, за умов екзо - та ендопатогених факторів» (номер держреєстрації 0115U000041), яка виконується впродовж 2015 - 2019 pp.

Поширеність наркоманії на сьогодні складає чи не найбільш важливу соціальну, економічну та медичну проблему багатьох країн світу $[1,3,4,5]$. На початку 2018 року в Україні зафіксовано 144 тис. наркозалежних, серед котрих 2 тис. виявились неповнолітніми. Вплив наркотичних середників на організм не обмежується змінами психіки. Опіоїдні наркотичні середники 3 древніх часів і до сьогодні є головними психотропними засобами, руйнівна мдія котрих стосується як психічного, так і соматичного здоровя [2]. Ріст наркоманії призвів до підвищення захворюваності та смертності серед наркоманів, при цьому у 50,9\% випадків її причинами є різні соматичні захворювання [30].

Значне використання наркотичних середників та поширеність наркоманії, що спостерігається впродовж останніх десятиліть серед населення $[46,66]$, зумовлює необхідність вивчення впливу опіоїдів на структурну організацію органів та систем $[6,11,12,40]$.

Одним із механізмів розвитку різноманітної соматичної патології, характерної для наркоманів, є безпосередня дія наркотиків на тканини і органи. Особливе місце в структурі патології внутрішніх органів при опійній наркоманії займають ураження гортані, печінки та нирок $[7,8,16]$.

До опіоїдів належать алкалоїди опійного маку (морфін, кодеїн та ін.), а також низка напівсинтетичних (героїн, налбуфін, етилморфін та ін.) і цілком синтетичних (метадон, 
трамадол та ін.) речовин, що специфічно взаємодіють 3 опіатними рецепторами головного мозку і таким чином реалізують свій наркотичний ефект. В останні роки щораз більшу частку опіоманів складають хворі, залежні від офіційних опіоїдів, які через порушення рецептурного режиму відносно вільно доступні в аптеках $[2,3]$.

Ураховуючи те, що больові відчуття становлять від 40 \% [5] до 90 \% [34] від усіх скарг при зверненнях за первинною медичною допомогою, проблема фармакотерапії та ефективного контролю болю залишається одним із найактуальніших завдань сучасної фармакології та медичної науки загалом [5, 60, 61, 62]. Вищесказане сприяє появі напрочуд широкого спектру антиноцицептивних медикаментів $[4,39,52]$. Відомо, що довготривалий біль супроводжується системною патофізіологічною реакцією цілісного організму 3 розвитком синдрому оксидативного стресу та чисельними порушеннями біохімічних реакцій в окремих клітинах [24, $32,64]$. Проведено ряд досліджень розвитку експериментального больового синдрому [19] 3 вивченням впливу різних методів знечулення [3, 29, 49, 51].

Загалом наркозалежні розглядаються у призмі терапії як модель наркологічної патології, часто 3 безремісійним перебігом, 3 додатковим тягарем коморбідних соматоневрологічних та інфекційних наслідків, інвалідизацією в молодому віці [35, 36]. У літературі наводяться дані щодо системного підходу до лікування і профілактики опіоїдної залежності та абстинентного синдрому $[32,49,56,60,63,65]$. Також розглядається принципово новий спосіб модуляції опіоїдної рецепції, що дозволяє призупинити перебіг морфінного абстинентного синдрому у щурів [31]. Запропонована гіпотеза мембранного механізму дії коменової кислоти пояснює результати, отримані під час експерименту, в яких показано пригнічуючий вплив коменової кислоти на поведінкові, больові та інші соматовегетативні прояви абстинентного синдрому у морфінозалежних щурів $[1,2,13,31]$. За сукупністю результатів аналізу доз встановлено також, що важкість синдрому відміни опіоїдів залежить від рівня проградієнтності на опійну залежність [43, 45, 50]. Узагальнюючи, можна зробити висновок, що впродовж минулих років вітчизняними та зарубіжними клініцистами та наркологами розроблено ряд ефективних методів детоксикації, які дозволяють у стислий термін припинити пролонговану наркотизацію, купірувати гостру клініку стану відміни, стабілізувати соматичний статус та досягнути етапу становлення терапевтичної ремісії [27, 28, 47].

Доведено, що хронічне отруєння наркотичними середниками викликає глибоку загальмованість загальної реактивності організму та резистентності відносно різноманітних інфекційних процесів, формує хронічну ендогенну інтоксикацію із закономірним розвитком хронічної поліорганної недостатності $[6,44,63]$.

Для виявлення психоактивних речовин (ПАР) у біологічних рідинах та тканинах організму людини проводиться забір та аналіз слини, сечі, волосся [14]. Усі три види біоматеріалів вважаються перспективними та мають різнонаправлені призначення [30]. Так, слину використовують для визначення стану наркотичного сп'яніння, сечу - для встановлення факту нещодавнього споживання ПАР [50], волосся дозволяє виявити анамнезу наркоспоживання цієї людини [22]. Для визначення ПАР використовують різні аналітичні методи, зокрема різноманітні види високотехнологічного імунохімічного аналізу: твердофазний імуноферментний аналіз, поляризаційний флюоресцентний імунний аналіз, радіоімунний аналіз [59]. Вище описана група методів частіше використовується для скринінгу зразків при масових дослідженнях, натомість при ідентифікації та кількісній оцінці ПАР у всіх видах біоматеріалу застосовуються хроматографічно-спектральні методи [37].

Окрім виявлення безпосередньо ПАР у біологічних об'єктах, визначаються ще й зміни метаболічних параметрів організму за умов впливу короткотривалої чи хронічної інтоксикації. Адже, як відомо, швидкість та спрямованість метаболічного процесу за екстремальних умов підлягають адаптативному регулюванню, що є беззаперечною умовою підтримання гомеостазу i резистентності організму [26]. Одним із механізмів їхнього забезпечення є активація детоксикаційної системи, особливе значення в якій має мікросомальна ферментативна система печінки та система антиокислювального захисту; ефективне функціонування останньої спрямоване на знешкодження реакційноздатних кисневих радикалів та ліпідних перекисів [30]. Оскільки наркотик взаємодіє 3 опіоїдними рецепторами, розміщення яких асоційоване 3 ліпідами клітинних мембран нервових клітин, основою порушення їхніх функцій $є$ зміна структурно-метаболічних характеристик ліпопротеїнових компонентів мембран нервових 
клітин в умовах опіоїдної залежності $[41,65]$. Наркотичній інтоксикації характерний дисбаланс ліпідного обміну, що реєструвався в мозку, крові, печінці, легенях та зумовлений розладами енергетичного метаболізму, призводячи до активного залучення поліненасичених жирних кислот до оксигеназних перетворень, що може мати небажаний деструктивний вплив на біологічні мембрани [30].

Суттєві метаболічні зміни, рання інвалідизація та смертність хворих із опіоїдною залежністю потребують вивчення патогенетичних механізмів прогресування множинних поліорганних коморбідних станів $[6,52]$. Цілеспрямованим вважається визначення метаболічних показників сироватки крові для оцінювання інтенсивності процесів цитолізу в тканинах печінки, холестазу, білково-синтетичної функції печінки, порушення холестеринового обміну [35, 36]. Доведено, що період гострої інтоксикації у хворих із опіоїдною залежністю супроводжується зростанням активності цитолітичних ферментів сироватки крові - аланінамінотрансферази, аспартатамінотрансферази, показників холестазу лужної фосфатази та гамма-глутамілтранс-пептидази, з подальшим підвищенням їхнього рівня у періодах ранньої і пізньої абстиненції. Установлено також залежність рівня активності креатинінфосфокінази MB і аспартатамінотрансферази в сироватці крові пацієнтів з опійною наркоманією в різні фази захворюваності [6].

3'ясовано, що лімфоцити хворих на полінаркоманію перебувають у стані активації апоптозу. Апоптоз, як відомо, присутній в усіх клітинних системах, а його механізмам та порушенням їхньої регуляції належить одне 3 провідних місць у виникненні запалення, звільнення організму від екзогенних та ендогенних патогенів, розвитку новоутворень, автоімунних, алергічних та імунодефіцитних станів $[50,58]$. Фізіологічна загибель клітини характеризується різноманітними морфологічними та біохімічними змінами ядра. При цьому під дією ендонуклеаз проходить фрагментація ДНК $[17,54]$. Визначення рівня фрагментованих ДНК у циркулюючому руслі та в лімфоцитах дозволяє оцінити глибину морфофункціональних змін в органах-мішенях і контролювати ефективність проведеної специфічної терапії на молекулярно-структурному рівні.

Вивчення будови судин, гістоструктури їхніх стінок у нормі та під дією різноманітних факторів дозволяє дослідити значення судинного фактора у морфофункціональній недостатності внутрішніх органів. Загальновизнано, що кожна функція базується на адекватній їй структурі. Судини гемомікроциркуляторного русла одними з перших реагують на патогенні фактори структурними змінами, які є підгрунтям для розвитку патологічного процесу та визначають його характер і особливості клінічних проявів $[15,42]$.

Макроскопічно уражені органи нагадуються картину, що супроводжує хронічні запальні захворювання. При цьому внутрішні органи нерівномірно кровонаповнені, більшість кровоносних судини спазмовані, кров у них переважно рідка, темна, з поодинокими пухкими згустками [18].

На основі проведених досліджень встановлено суттєву перебудову органів гепатобіліарної системи залежно від дози спожитих наркотичних речовин та важкості наркоманії $[9,35,57]$. З'ясовано закономірність специфічних змін внутрішніх органів і стан серцево-судинної системи у пацієнтів з опійною наркоманією в аспекті потогенезу. Виявлено характерні соматичні особливості при споживанні наркотичних середників та встановлено, що провідна роль у цьому процесі належить патології серцево-судинної системи - прогресуванню токсичної кардіоміопатії [25, 49], бактеріальному ендокардиту з наявністю малих тромбів без деформації клапана [18]. Проте більшість учених, що вивчають дію опіоїдної інтоксикації, схильна вважати, що провідними у процесі патогенезу є «мозкова» та «серцева» смерть [30].

Під дією наркотичних речовин у головному мозку виявлено ознаки набряку та набухання його тканин, а також набряк оболон мозку $[20,21]$. Це пояснюється поєднанням порушення мікроциркуляції, характерного для гострої інтоксикації наркотиками, та серцево-судинної недостатності, пов'язаної з пошкодженням дихального центру, наростанням набряку легень i ураженням серця. Гістологічно, окрім набряку дренажної глії, що проявляється мікроскопічно навколосудинним та перицелюлярним набряком, виявлено різноманітні порушення мікроциркуляції у вигляді стазу еритроцитів у капілярах, загального венозного повнокров'я, парезу резистентної ланки мікроциркуляції, сладжу еритроцитів, іноді утворенню фібрино-еритроцитарних тромбів i множинних дрібних діапедезних крововиливів у субкортикальні відділи та в стовбур мозку. Зрідка 
крововиливи захоплюють м’яку мозкову оболону. Крововиливи у стовбур головного мозку пов'язуються 3 гострим загальним венозним повнокрів'ям гіпоксичного генезу і 3 порушенням реологічних властивостей крові. Виявлено зміни при зафарбовуванні за методом Нісля, а саме: набухання, ішемічні зміни нейронів кори та важкі зміни нейронів підкіркових ядер і стовбура 3 досить помірними явищами сателітозу та нейронофагії, які можна пояснити тим, що наркотичні середники діють первинно на структури лімбічної системи, а інші нервові апарати пошкоджуються вторинно $[10,37]$. При субмікроскопічному дослідженні виявлено підвищену кількість піноцитозних пухирців у цитоплазматичних відростках ендотеліальних клітин 3 утворенням вакуолей різних розмірів. Відростки нейронів мають вигляд звивистих, ущільнених. У стовбурових відділах виявляються множинні ділянки 3 порушенням будови гліальних оболонок нервових волокон, їхнім набряком i деформацією. Проліферативна реакція глії виявляється домінантно навколо пошкоджених нейронів. Значна кількість гліальних клітин є зруйнованою. Електронномікроскопічно спостерігаються розриви плазмолеми, конденсація гетерохроматину під каріолемою, деструкція системи органоїдів [13].

У легенях внаслідок застосування наркотичних середників при макроскопічному дослідженні виявлено ознаки масивного набряку. Досить часто наявні крововиливи як субплеврально, так і в глибоких відділах легень. Нерідко спостерігаються пневмонії, що очевидно свідчить про імунодефіцитні стани та проведення нестерильних ін'єкцій при наркоманії. Виявлено гістологічну картину стромального та інтерстиційного набряку, повнокрів'я, інтраальвеолярні субсегментарні гострі крововиливи і явища стазу та сладжування еритроцитів у судинах мікроциркуляторного русла, пов'язані з порушенням регуляції функції кровообігу [10]. Патологія легень характеризується мікро- та макроінфільтратами, представленими гранулоцитами, лімфоцитами, що супроводжується локальними некрозами судинної стінки і тромбоемболіями дрібних гілок легеневої артерії. Значно рідше спостерігаються мікроінфаркти з бактеріальними мікроабсцесами [18]. Окрім цього, виявлено ознаки вогнищевого гемосидерозу, дистелектазів та емфіземи, фібринові тромби в артеріолах, капілярах, ушкодження альвеолоцитів, а також гіалінових мембран.

При тривалому застосуванні опіоїдів гістологічно підтверджено наявність в серцевосудинній системі численних дрібновогнищевих ділянок кардіосклерозу, рабдоміолізу, жирової трансформації міоцитів. Це свідчить про важливу роль некоронарогенних механізмів виникнення фіброзу серцевого м’яза, який у свою чергу причетний до розвитку фібриляції. Окрім цього, виявлено фрагментацію пошкоджених кардіоміоцитів, парез мікроциркуляції, вогнища гострих крововиливів. Зафарбовуванням за Рего описано нерівномірне сприйняття барвника, що свідчить про метаболічне пошкодження міокарда, швидше за все ішемічного генезу [38].

До морфологічних проявів токсичного впливу наркотиків на травну систему належать: поширений карієс, втрата зубної емалі, пародонтоз. Рідше зустрічається ерозивний стоматит, езофагіт, гастрит [18]. Для печінки характерні ознаки жирової дистрофії та застійне повнокрів'я портальних трактів. Мікроскопічно прослідковується картина хронічного персистуючого гепатиту, при цьому спостерігається перипортальна клітинна запальна інфільтрація і дистрофічні зміни гепатоцитів, включно до вогнищевих некрозів. Нерідко прослідковується активація та проліферація портальних і синусоїдальних ендотеліоцитів у вогнищі грануломатозного запалення [18].

Макроскопічно для наднирників характерна світло-жовта кіркова речовина та коричнева мозкова без ознак розплавлення, тоді як мікроскопічно спостерігалися ділянки 3 втраченою структурою клубочкової зони, відсутністю границі між зонами кори, виявлення вогнищевої деліпоїдизації, тобто характерна атрофія кори з наявністю множинних вузликів, що підтверджено гістологічно $[5,2]$. Гемодинамічні порушення характеризувалися повнокрів'ям, проявами стазу еритроцитів, формуванням сладжів та тромбоутворенням. Крім цього, спостерігали пікнотичні ущільнені ядра хромафінних і підтримувальних клітин, вакуолізацію цитоплазми [2].

Патологія нирок носить здебільшого вторинний характер, що пов'язано 3 бактеріальною, вірусною чи грибковою інфекцією. Морфологічна специфічна форма ураження нирок у вигляді героїнової нефропатії, для якої характерне залучення імунних механізмів до розвитку мезангіокапілярного гломерулонефриту, спостерігається рідко. Частіше в корі, аніж у мозковій речовині нирки, є вогнища продуктивного запалення, представлені фібробластами, макрофагами, поодинокими еозинофілами та нерідко епітеліоїдними клітинами. У них також відзначено вторинні дрібновогнищеві некрози уротелію [13]. 
3 точки зору окремих авторів, підвищена небезпека при вживанні наркотиків, призводить до вивільнення гістаміноактивного медіатора запалення і розвитку алергічних реакцій [18]. Окрім цього, відсутність стерильних умов при приготуванні та введенні наркотичних речовин небезпечна не лише з токсикологічної точки зору, але й тому, що $є$ імунопатогенним чинником, що призводить до виникнення атипового та прогресуючого перебігу інфекції з іiі швидкою генералізацією і органним пошкодженням. Оскільки при наркоманії домінує парентеральний метод введення, характерними є зміни шкіри в місцях введення наркотичних середників. Морфологічні особливості слідів ін'єкції мають мозаїчну картину, та здебільшого представлені дрібнокрапковими ранами чи мікрослідами у вигляді ланцюжків у проекції вени, рідше спостерігаються виразкові дефекти шкіри, поєднані $з$ рубцевою деформацією. Виразкові дефекти та ерозивні поверхні мають кратероподібний характер із підритими краями і запальним валиком, покритим кірочкою коричневого кольору. Епідерміс у цих зонах значно стоншений, з нерівною поверхнею та інверсією базальних шарів 3 явищами акантозу. Власне в дермі наявні щільні сполучнотканинні утвори у вигляді тяжів 3 ознаками келоїду, що повторюють анатомічне розташування судин. У субепідермальній зоні виявляються вогнища крововиливів різного терміну утворення, продуктивного запалення за участю гранулоцитів, дистрофічно змінених клітин сполучної тканини та лімфоїдних елементів [7, 23]. У просвіті судин зустрічаються організовані пристінкові тромби 3 вторинною каналізацією. Часто виявляється повна оклюзія судин. М'язові волокна прилеглих скелетних м'язів стоншені, деформовані, в них виявлено жирові вакуолі, виражений інтерстиційний склероз та фіброз, границя між запальними інфільтратами та м'язовою тканиною $є$ нечіткою [18].

Таким чином, аналіз фахової літератури свідчить, що проблема етіологічних чинників та патогенетичних механізмів розвитку захворювань гортані залишається надзвичайно актуальною для сучасної медичної науки. Вирішення цього питання неможливе без глибоких фундаментальних досліджень морфологічних особливостей гортані в нормі та за умов патології. Проблема впливу опіоїдних речовин на перебудову організації органів та систем $\epsilon$ важливою та актуальною для сучасної медицини. Багато питань, що стосуються структурних змін тканин при застосуванні наркотичних засобів, залишаються невирішеними. Дані фахової літератури щодо цієї проблематики суперечливі та вимагають уточнення.

\section{ЛIТЕРАТУРА}

1. Овчаренко НА, Пинский ЛЛ, Радченко ТН. [та ін.] Динамические изменения показателей цитолиза, холестаза и липидограммы у наркозависимых больных. Український журнал клінічної та лабораторної медицини. 2012. Т. 7, № 4. С. 116-119.

2. Дісковський IC. Особливості мікроструктури шкіри щура за умов впливу опіоїду. Експериментальна і клінічна медицина. 2014. № 3. С.61-64.

3. Егоров ЕА, Ставицкая ТВ, Тутаева ЕС. Офтальмологические проявления общих заболеваний. М.: ГЭОТАР Медиа, 2006. 592с.

4. Табачніков СІ, Лєбєдєв ДС, Трофімчук ГС. [та ін.] Епідеміологічна ситуація щодо вживання психоактивних речовин в Україні. Архів психіатрії. 2009. Т. 15. № 1 (56). С.81-88.

5. Жабоедов ГД, Радченко МР, Носов АТ. Морфофункциональное состояние сетчатой оболочки глаза при метаноловой интоксикации. Офтальмологический журнал. 2003. № 2. С.67-71.

6. Зінько АВ, Матешук-Вацеба ЛР. Вплив опіоїду на ультраструктуру променистого вінця кінцевого мозку в експерименті. Світ медицини та біології. 2014. Т. 4, № 47. С.127-130.

7. Казаков ВН, Панова ТИ, Панова ЛЕ. Стресс у крыс с морфийной зависимостью: антистрессорные свойства коменовой кислоты. Нейрофизиология. 2003. Т. 35, № 5. С.425-430.

8. Кахановський $\Phi \mathrm{M}$, Москаленко ВС. Можливості ідентифікації, кількісного визначення деяких міорелаксантів у біологічних матеріалах. Український медичний альманах. 2011. Т. 14, № 1. С. 104-105.

9. Керечанин IB. Структурні зміни судинної стінки ланок гемомікроциркуляторного русла і клітин тимуса за умов дії метилтрибутолового ефіру в експерименті: автореф. дис. на здобуття наук. ступеня канд. мед. наук: [спец.] 14.01.01 «Нормальна анатомія» К., 2011. - 20c.

10. Климочкина ЕМ, Сухоставская НА. Связь апоптотических процес сов в условиях селективной и неселективной активации опиатных рецепторов в культуре клеток с сотоянием миттохондриальных К+ АТФ - зависимых каналов. Український журнал клінічної та лабораторної медицини. 2012. Т.7, № 4. С.52-55.

11. Солодун ЮВ, Лелюх ТД, Маслаускайте ЛС. [и др.] Клинико-морфологические параметры героиновой наркомании и связанной с ней патологии. Судебно-медицинская экспертиза. 2001. № 6. С.6-10.

12. Кобеляцкий ЮЮ. Современные аспекты использования смешанного агониста-антагониста опиоидных рецепторов налбуфина в клинической практике. Острые и нетложные состояния в практике врача. 2012. № 1. С.61-64. 
13. Литвинцев БС. Структурно-функциональные изменения нервной системы при хроническом отравлении опиоидами: автореф. дис. на соискание учен. степени канд. мед. наук.: [спец.] 14.00.18 «Психиатрия» М., 2003. 23c.

14. Литвинцев БС, Одинак ММ, Гайкова ОН. Клинико-морфологическая характеристика неврологических проявлений наркомании. Профилактич. и клин. мед. 2011. Т. 39, № 2. С.99-104.

15. Мальцев ЭВ, Зборовская АВ, Дорохова АЭ. Состояние сетчатой и сосудистой оболочек глаза кролика с сахарным диабетом, моделированным дитизоном. Сообщение 4. Сравнительное морфологическое сопоставление феномена нейродегенерации при дитизоновом и стрептозотоциновом диабете. Отальмологический журнал. - 2012. - № 5. - С.60-65.

16. Мальцев ЭВ, Зборовская АВ, Дорохова АЭ. Состояние сетчатой и сосудистой оболочек глаза кролика с сахарным диабетом, моделированным дитизоном. Сообщение 2. Антиоксидантные энзимы и супероксидный кислород. Офтальмологический журнал. 2012. № 3. С.61-67.

17. Матешук-Вацеба ЛР, Кирик ХА. Морфометричний аналіз змін гемомікроциркуляторного русла райдужки і війкових відростків очного яблука за умов експериментального діабету. Таврический медико-биологический вестник. 2006. Т. 9, № 3, Ч. 1. С. $108-110$.

18. Матешук-Вацеба ЛР, Кирик ХА. Про раціональну методику ін'єкції судинного русла. Клінічна анатомія таоперативна хірургія. - 2004. - Т. 3, № 3. - С.53.

19. Табачников СИ, Харченко ЕН, Приб ГА. [и др.]Медико-социологические аспекты характеристики токсикомании у лиц подросткового и молодого возраста. Архів психіатрії. 2011. Т. 17, № 3 (66). С.61-66.

20. Меркулов ГА. Курс паталогогистологической техник. Ленинград: Медицина, 1969. $406 c$. НефьодовОО, МамчурВЙ, Опришко ВI. [та ін.] Місце неопіоїдних анальгетиків та роль оксиду азоту в механізмах болю та спазму. Український медичний альманах. 2011. Т. 14, № 2. С.46-51.

21. Нефьодов ОО, Мамчур ВЙ, Опришко ВІ. [та ін.] Місце неопіоїдних анальгетиків та роль оксиду азоту в механізмах болю та спазму. Український медичний альманах. 2011. Т. 14, № 2. С.46-51.

22. Бойко ЭВ, Чепур СВ, Позняк АЛ. [и др.] Особености поражения структур заднего отрезка глаза при экспериментальной хламидийной инфекции. Вестник офтальмологии. 2010. № 1. С.27-32.

23. Паніна ЛВ,ТерлецькаСМ, Ковальчук СМ. [та ін.] Оцінка ендогенної інтоксикації організму за умов експериментальної гемічної гіпоксії. Здобутки кліні

24. Пат. №76564 U Україна, МПК А 61 К 31/00 Спосіб моделювання фізичної опіоїдної залежності у щурів/ заявники: Онисько РМ, Пальтов СВ, Фік ВБ. [та ін.]; патентовласник: Львівський національний медичний університет імені Данила Галицького. - №u201207124; заявл. 12.06.2012; опубл. 10.01.2013, Бюл.№1.

25. Бухтіарова ТА, Губський ЮІ, Літвінова НВ. [та ін.] Процеси перекисного окислення ліпідів та обмеженого протеолізу за моделювання больового синдрому запального генезу та дії анальгетиків. Матеріали IV Національного 3’їду фармакологів України : тези доп. Київ, 2011. С.43.

26. Радомский ВТ, Серёгина НМ, Остапенко ИИ. Опыт применения Налбуфина при лучевом лечении метастазов в кости. Український медичний альманах. 2014. Т. 17, № 3. С.82-84.

27. Балакірєва ОМ, Бондар ТВ, Рингач НО. [та ін.] Рівень і тенденції поширення тютюнокуріння, вживання алкоголю та наркотичних речовин серед учнівської молоді України. К.: УІСД ім. О.Яременка, 2008. 152c.

28. Рудковська ОД. Генетичні основи етіопатогенезу очних захворювань. Клінічна та експериментальна патологія. 2010. Т. 9, № 2. С.99-100.

29. Брюн ЕА, Мягкова МА, Морозова ВС. [и др.] Сравнительниый опит определения наркотических веществ в России и за рубежом / // Вопросы наркологии. - 2011. - № 1. - С.9-16.

30. Степанов ВГ. Математическое моделирование ангиографических исследований структурнофункциональной организации кровеносных сосудов и кровоснабжения ими зон микроциркуляции. Український морфологічний альманах. 2004. Т. 2, № 1. С.72-74.

31. Логвинов СВ, ПлотниковМБ, Жданкина АА. [и др.] Структурные нарушения хороидоретинального комплекса глаза при тотальной транзиторной ишемии головного мозка и их коррекция. Морфология. 2011. Т. 140, № 6. С.43-47.

32. Сушик ОГ, Василюк СМ. До питання про наркоманію в Україні. Педагогічний пошук : наук.-метод. вісн. 2010. № 2. С.41-44.

33. Кривко ЮЯ, Матешук- Вацеба ЛР, Масна 33. [та ін.] Ультраструктура ланок гемомікроциркуляторного русла в нормі та за умов експериментального цукрового діабету. Вісник морфології. 2010. Т. 16, № 2. С. 397-401.

34. Матешук-Вацеба ЛР, Гунас IB, Дац РI [та ін.]Ультраструктурні особливості війкових відростків очного яблука під впливом цукрового діабету та ендоваскулярного лазерного опромінення крові. Biomedical and biosocial anthropology. 2010. № 14. C.56-58.

35. Шаповалов В. В. Судова фармація в державній системізаходів узагальнення причин і умов поширення наркозлочинності та наркоманії (на засадах криміналістики). Юридичнйи журнал. 2011. № 6. С.41-45.

36. Шаповалов ВВ.(мол.). Доказова фармація: способи детоксикаційної фармакокорекції наркозалежних пацієнтів. Український вісник психоневрології. 2010. Т. 18, № 2. С.63-64.

37. Шенк ЯО. Особливості патоморфологічних змін структур органа зору при генералізованому туберкульозі. Український пульмонологічний журнал. 2005. № 1. С.44-45.

38. Ядловський ОЄ, Мовчан ОД. Фармакологічний аналіз опіоїдергічного компоненту дії анальгетика піродазолу. Фармакологія та лікарська токсикологія. - 2011. Т. 3, № 22. С.73-77. 
39. Якимів НЯ, Кривко ЮЯ. Мікроструктурна характеристика райдужно-рогівкового кута очного яблука щурів при опіоїдному впливі. Світ медицини та біології. 2013. № 4. С.117-120.

40. Логаш М, Покотило П. Деякі аспекти історії опіатів в контексті сучасних проблем наркозалежності. Світ Медицини Та Біології.2013;4(41):126-9.

41. Онисько Р, Фік В, Фітькало О, Пальтов С, Кривко Ю, Вільхова І. Спосіб моделювання фізичної опіоїдної залежності у щурів [Internet]. Львів; 76564, 2013 [cited 2016 Nov 30]. Available from: http://uapatents.com/4-76564-sposib- modelyuvannya-fizichno-opiodno-zalezhnosti-u-shhuriv.html

42. Якимів Н, Кривко Ю. Мікроструктурна характеристика райдужно- рогівкового кута очного яблука щурів при опіоїдному впливі. Світ Медицини Та Біології. 2013;9(4-2(42)):117-20.

43. Підвальна У, Джура О, Матешук-Вацеба Л. Морфологічнізміни судинної оболонки очного яблука за умов тривалого впливу наркотичних анальгетиків. Світ Медицини та Біологіi.2017;13(3):142-145.

44. Попик П. Особливості мікроструктури підшлункової залози білого щура за умов впливу опіоїду. Вісник Проблем Біології І Медицини. 2014;(3 (2)):310-313.

45. Попик ПМ. Морфометрична характеристика змін ланок гемомікроциркуляторного русла підшлункової залози під впливом налбуфіну. Актуальні Проблеми Сучасної Медицини Вісник Української Медичної Стоматологічної Академії [Internet]. 2013 [cited 2016 Nov 29];13(4 (44)). Available from: http://cyberleninka.ru/article/n/morfometrichna-harakteristika-zmin-lanok-gemomikrotsirkulyatornogo-ruslapidshlunkovoyi-zalozi-pid-

46. Зінько А. Особливості структури та гемомікроциркуляторного русла променистого вінця за умов двотижневого впливу опіоїду в експерименті. Клінічна Анатомія Та Оперативна Хірургія.2015;14(3):44-47.

47. Зінько А, Костюк Г. Мікроструктурна організація мозолистого тіла кінцевого мозку за умов впливу опіоїду в експерименті. Вісник Проблем Біології I Медицини.2016;2(2):117-120.

48. Логаш М, ПокотилоП, Федевич Ю, Кривко Ю. Зміни біохімічних показників крові щура при інтоксикації опіоїдами в динаміці перебігу експерименту. Експериментальна I Клінічна Медицина.2014;3(64):78-81.

49. Дісковський IC. Морфологічні особливості шкіри та процесів репарації під впливом опіоїду в експерименті [Авт.дис.наздоб. ст. канд.мед.наук]. [Львів]: Львівський національний медичний університет імені Данила Галицького;2016.

50. Головацький А, Гарапко Т. Структурні зміни тимуса при дії на організм опіоїду. Науковий Вісник Ужгородського УніверситетуСерія Медицина. 2017;(1):15-21.

51. Adhi M, Brewer E, Waheed NK. [etal.]Analysis of morphological features and vascular layers of choroid in diabetic retinopathy using spectral-domain optical coherence tomography. J.Am.Med.Ass.Ophth.2013.Vol.131,№10. P.210-218.

52. Ahmad Fadzil MH, Nugroho H, Izhar LI. [et al.] Analysis of retinal fundus images for grading of diabetic retinopathy severity. Med. Biol. Engin. Comp. 2011. Vol. 49, № 6. P.693-700.

53. Tarnutzer AA, Gerth-Kahlert C, Timmann D. [et al.] Boucher-Neuhäuser syndrome: cerebellar degeneration, chorioretinal dystrophy and hypogonadotropic hypogonadism: two novel cases and a review of 40 cases from the literature. J. Neur. 2015. Vol. 262, № 1. P.194-202

54. Clausen T, Anchersen K, Waal H.Mortality prior to, during and after opioid maintenance treatment (OMT): a national prospective cross-registry study. Drug Alc. Dep. 2010. Vol. 94, № 1. P.151-157.

55. Florentina D, Villena A, Vidal L. [et al.] Experimental model of ocular hypertension in the rat :study of the optic nerve capillaries and action of hypotensive drugs. Inv. Ophth. Vis. Sci. 2010. Vol. 51, № 2. P.946-951.

56. Vranka JA,. Kelley MJ, Acott TS., [et al.] Extracellular matrix in the trabecular meshwork: Intraocular pressure regulation and dysregulation in glaucoma. Exp. Eye Res. 2015. № 13. P.112-125.

57. Hayreh SS. Management of ischemic optic neuropathies. Ind. J.Ophth. 2011. Vol. 59, № 2. P.123-136.

58. Millonig G. Advantages of a phosphate buffer for OsO4 solutions in Kiration J.Appl. Phys. - 1961. № 32. 1637p.

59. Mohamed Q, Gillies MC, Wong TY. Management of diabetic retinopathy: a systematic review. J. Am. Med. Ass. 2007. Vol. 298, № 8. P.902-916.

60. Akshat S, Ramachandran R, Rewari V. [et al.] Morphine versus Nalbuphine for open gynaecological surgery: a randomized controlled double blinded trial [Електронний ресурс]Pain Res. Treat. 2014. Режим доступу:http://www.hindawi.com/journals/prt/2014/727952/.

61. Schnabel A, Reichl SU, Zahn PK. [et al.] Nalbuphine for postoperative pain treatment in children [Електронний ресурс]. Cochr. Lib. 2014. Режим доступу: http://onlinelibrary.wiley.com/doi/10.1002/ 14651858.CD009583.pub2/full.

62. Narver HL. Nalbuphine, a non-controlled opioid analgesic, and its potential use in research mice. Lab. An. 2015. Vol. 44, № 3. P. 106-110.

63. Copeland L, Robertson J, McKenzie J. [et al.]Premature mortality in Scottish injecting drug users: a lifehistory approach. Scott. Med. J. 2012. Vol. 57. P. 59-65.

64. Stitt AW, Curtis TM. Advanced glycation and retinal pathology during diabetes. Pharm. Rep. 2005. № 57. P.156-168.

65. Deering D, Sellman JD, Adamson S. Opioid substitution treatment in New Zealand: a 40 year perspective. N Z Med J Online.2014;127(1397):57-66.

66. Cao X, Wu Z, Rou K, Li L, Lin C, Wang C, et al. Retention and its predictors among methadone maintenance treatment clients in China: a six-year cohort study. Drug Alcohol Depend.2014;145:87-93. 